\title{
The World's Far Side: Being and It's other in the Poetry of Boleslaw Lesmian
}

\author{
Amechi N. Akwanya \\ Department of English and Literary StudiesUniversity of Nigeria, Nsukka
}

\begin{abstract}
The poetry of Lesmian is among the most striking of the entire modernist tradition. The format is often narration, but the incidents and the sequences that unfold are so far removed from human experience as to raise questions of overall intelligibility. As an order of words, the poems are also strange and alienating because the words are not always established members of the repertoire and often name entities and actions outside the realm of the knowable. As a result, meaning is hard to work out at any level literal or figural. But they always have an arresting quality that cannot be ignored. The readings available in English are not many, but the arguments for the ultimate cause of the poetry in a vision thought to be the author's tend to be purely speculative. In this paper, based on the understanding of poetry as a movement of thought, risked and satisfied, as Roland Barthes would say, the poems are seen as following the possibilities of existence beyond the exclusive antonyms, being and nothingness. At the risk of an epistemology having the entire oeuvre in its sights instead of the poems as individual and independent utterances, use is also made of the features which recur or re-echo across poems as threads to activate a dialogue between them.
\end{abstract}

Keywords: epistemology, intelligibility, myth, self-sufficiency, sufficient reason

\section{Introduction}

Paul Coates rates Boleslaw Lesmian as 'the greatest of the twentieth-century Polish poets, and one of the greatest of modern Europeans ones' (1986: 99). The poetry, however, is not readily accessible as it challenges intelligibility both at 'the level of epistemology and of social dynamics' (Holquist 1990: 66), which are the mastercodes conventionally used for reading poetry and literature. 'Bees', for instance, undeniably strong writing with endless 'ontological or metaphysical manoeuvres', as John Crowe Ransom would say, hardly yields the 'total poetic or individual object which tends to be universalized'in the event of reading (1972: 238). The sequence unfolds by virtue of bees straying 'from the pathway of being' in an 'underground seclusion'; and we read,

So strange is the glittering swarm's humming jive

One is fearful of watching it eagerly gleaming! ...

And the dead, quite delighted, eyes flickering wide,

Their dry stick hands raised up as shields from the glare,

Crowd shade upon shade and concertedly cry,

'They're bees! You remember? They're bees; that's for sure!'

We do not expect recognizable scenes in this poem because 'the fantastic', as Stone shows, is 'precisely what constitutes the distinctive feature of Lesmian's poetry' (1976: 190). In the above'underground seclusion', the Bees'humming awakens the dead, who recall in their hebetude the ghosts in the Homeric underworld. Lesmian'sperform one great act before the marvelous moment passes, namely recognition that these are bees.

Remembering their former knowledge of bees is at the same time the awakening for the dead the pangs and pains they had had during their lifetime, which death had put to 'sleep'. Then the moment passes as the bees find their way back to 'the pathway of being':

On reaching the world their light dies at the corner.

All gone! And the dead watch and watch where they went ...

There is undoubtedly nostalgia in the dead watching and watching where the bees have gone, but there is no motion in them. Beyond what Sandauer calls the 'mythology of the moment' (Stone 1976), it is hard to see the point of this flight from 'the world', 'outside the pathway of being', and back againand the momentary awakening of consciousness among the dead.

Circumscribed within the poem, the momenthardly assists in settling or ascertaining one's bearings, as would be the case with moments in the world intersecting with events. The poem also creates a kind of space, another element essential for localization and taking of bearings: it localizes things within the poem, but does not 
suggest a connection between the poem and the outside. The poem is therefore not what Derrida would call 'a signifying chain in scenic form' (Writing and Difference 275), but probably 'pure literature', to be 'respected in its irreducibilty' (Of Grammatology 59). This is the case with Lesmian's poetry as a whole;consequently they resist reduction to any kind of 'social dynamics'.

In some cases like 'Pan Blyszczynski', the epistemological question is not primarily about the overall sense, but the basic semantics of words and word groups. The opening stanza of this poem reads:

Pan Blyszczynski's garden is greening in the outdusk

Where miracle distends to horrid lawlessness.

He extroduced it with his flashing eyes from nothing's husk

And fixed it under trees upon dreamt-up grass.

We immediately see possible words like 'outdusk' and 'extroduced' in which there is probably some ground to construct a meaning. But 'nothing's husk' seems to be altogether impossible to interpret. While And fixed it under trees upon dreamt-up grass does not seem to cause semantic problems at the level of individual words and phrases, the whole sentence (with the deleted subject) is profoundly enigmatic and if one is hesitant to dismiss it as meaningless, because this is part of a poem, one is faced with the problem how to make sense of it. This is the question of intelligibility, which Habermas apparently refers to linguistic analysis for resolution:

The intelligibility of an utterance can be challenged by questions such as 'What does that mean?' or 'How should I understand that?' The answers to these questions are to be found in the structure of language itself (Thompson 262).

'The structure of language', generally understood in terms of grammatical rules, would shed but little light on Lesmian's verse above, since the sentential components are all interrelated in proper order. Being 'part of a poetic text' (Foucault 1972: 90), is why the sentence may not be dismissed as unacceptable, despite its oddity. But it appears quite uninterpretable, at least by the rules of propositional semantics which work by assigning fixed values to especially the nominals in an utterance.

\section{Reading Practices}

Interpreting poems in propositional terms raises specific issues. Since a nominal can function like a deictic element in discourse, it implicates the speaker (and perhaps the writer, the poet) in the process of singularizing the thing meant. According to Paul Ricoeur,

'Reference is itself a dialectical phenomenon. To the extent that discourse refers to a situation, to an experience, to reality, to the world, in sum to the extra-linguistic, it also refers to its own speaker by means of procedures that belong essentially to discourse and not to language' (86).

Hence the question of intelligibility of Lesmian's verse could be framed in terms of what he means. The view is now taken as commonsensical that one who creates a linguistic event must have an intention in doing so and that this intention or purpose is a sufficient reason for the poem. It is in fact a philosophical position, that 'sufficient reason signifies only sufficient conditions [and] all other considerations are irrelevant, and it is proper to ignore them' (Perry 2008 § 46).Apart from this commonsensical view,the much less discussed fact of reference simultaneously to the extra-linguistic and to the speaker is the reason for the great deal of attention often paid to the poet in discussions of poetry. The presupposition in such discussions is that the referentials in the poem belong to the world of the poet and are therefore what he or she is concerned with.

In Heidegger's approach to the question of the relationship of the real, history, phenomena in general to the poem in which it features and what it may have to do with the 'existentialistic structure' of the work (Werner Brock 1949: 32), there is frank admission that the concrete facts named by the poem lead back to the author. For him, however, the focus is on the poem itself as the sufficient reason for the linguistic event:

'we must always be practising thinking about the poet afresh in the only way in which it can begin. That is the attempt to think about what has been made into poetry. Such an act of remembrance arises out of a dialogue between thought and the writing of poetry, although at first the dialogue itself and what is spoken of, are not mentioned.

What has been made into poetry is preserved in the poem (253).

'Nothing's husk' as much as 'Blyszczynski's garden' itself is part of 'what has been made into'Lesmian's 'Pan Blyszczynski' and 'preserved in the poem'. Poetry is 'the function that incorporates them within the text' (Kristeva 1980: 37). Heidegger's 'we must always be practising thinking about the poet' is almost as a matter of piety. But it is undoubtedly the case that the poet deserves homage, and that there is homage in contemplating his/her works. A distinction nevertheless holds between poem and poet; and 'nothing's husk', an example of what Paul Coates calls 'Lesmian's estrangement of language' and 'distrust of words' (131), is very important in 'Pan Blyszczynski' 
precisely because it lacks the character of a 'sign' in the referential format, having no truth-value. It belongs entirely to the world of the poem of which Northrop Frye writes,

In literature, questions of fact or truth are subordinated to the primary literary aim of producing a structure of words for its own sake, and the sign-values of symbols are subordinated to their importance as a structure of interconnected motifs. Wherever we have an autonomous verbal structure of this kind, we have literature (1970: 74).

Lesmian's work asserts itself as a poem, and could be nothing else, and its 'structure of interconnected motifs' is really part of why it is so arresting.

Recently, some of Boleslaw Lesmian's poetry has become available in PoemHunter.com, but it is mainly Rochelle Stone and Paul Coates that one must thank for introducing him with translations and serious criticism of his poems. Apart from these two, there is very little criticism of Lesmian's work available in English. Some of the discussion, however, has been biographical - but not verifiable biography. We read of a female figure frequently encountered in Lesmian:

'A good example of the polysemia of his images is that of 'the non-existent girl'. I can only mention some of the causes of her non-existence: the pregnant, mythical quality of her image provokes a strictly interminable reflection. She is the poet's anima or other; she is merely an imaginary projection, so that in ascribing a fictional character to her the verse hints at its own epistemology; unseen in the darkness in which the act of love conventionally occurs, she is everyone - and hence no one; she is the silent, idealized peasant girl of Young Polish iconography, and her taciturnity renders her no more than a screen for the poet's projections (a waxdoll upon whom his jealous vengeance on other women is wrought); she represents the impossible synthesis of Lesmian's wife and his mistress; and she is also - as Sandauer has suggested - the semi-real lover conjured by the onanist' (101-102).

Paul Coates's highlighting of 'neologism' as a dominant process in Lesmian's poetry, which encourages the search for an original sense, as the 'signified' of the linguistic novelty ultimately depends on conjecture. His reading of the non-existent girl similarly demands an original. Intelligibility attained by pure conjecture will always leave a sense that the study of the work itself is yet to be undertaken.

Rochelle Stone, on the other hand, is concerned with Lesmian's intention - that intention embodied in what is called 'poetics'. Concerning this, Northrop Frye has written, 'a poet intends to produce, not simply a poem, but a certain kind of poem' (86-87). Stone's main interest, therefore, is to account for Lesmian's art, together with what he has made into the poem, which is preserved in the poem. Her manner of making the case, however, is as if Lesmian is faithfully reproducing what he actually sees:

'Things, facts, and events are of interest to him in the form in which they actually occur at a given moment. Since his attention is focused on the phenomena themselves, we can call his attitude phenomenalism. It is manifested in not showing the causes of phenomena, a device of particular significance in Lesmian's poetics. His lack of concern for causality allows him to present things in motion and in a state of change without logical order. Phenomenalism is often a basis in constructing plots. Instead of a causal chain, Lesmian juxtaposes events and descriptive elements in a sequence in which they actually occur, without trying to explain them' (1976: 191). Stone makes a very strong case that the kind of poem is Symbolist, with its 'vision of a world governed by its own laws' (194), yet assigning to the reader the 'active role' of creating a synthesis out of the mass of 'things, facts, and events'.

As TzvetanTodorov (1980) has shown, model building, strategies of totalization in general are always involved in the reading of literary works. Unlike in in the novel with its illusion 'born from the fusion of two heterogeneous enterprises in one principle [which] compose an autonomous verbal structure and represent real life' (Ricoeur 1984: 164n), creating a synthesis in Symbolist poetry is a highly demanding task, because everyday models rarely seem to fit. Much of modernist literature behaves the same way and tends to leave out the average reader, whose models for reconstructing the worlds of literary texts are derived exclusively from lived experience: history, social systems and social relations.

The basis of all constructions, however, is the language. The difficulty with constructing coherent worlds in Lesmian's poetry arises from signifiers of which the signifieds cannot be recovered from the language system and predicative syntagms bereft of denotables. In this paper, we shall aim to attain an understanding of the poetry by exploring the internal network of the poems and by activating a dialogue among these poems. BringingLesmian's poetry all into dialogue with one another may give the impression that they have 'a common purport' (Hervey 1979: xxiii), or that the poems are signs left here and there to be pieced together to attain Lesmian's intended meaning. This would be 'logocentric teleology' (Of Grammatology 82). Reading by activating a dialoguemay be seen as a motif of poststructuralism, and arises from the theory of intertextuality.Holquisthowever explains its viability as an epistemology: 
'Dialogism may indeed be defined as an epistemology based on the assumption that knowing an entity (a person or a thing) is to put that entity into a relation of simultaneity with something else, where simultaneity is understood as not being a relation of equality or identity' (154).

\section{Beyond the Categories of Being and Nothingness}

Derrida's Of Grammatology exposes language in a way that is hitherto unprecedented by unveiling a complicity between it and metaphysics; the result is that the critique of 'the metaphysics of presence' is at the same time the critique of language, and the critique of literary criticism. This philosophical tradition has so shaped thought that thought is quite incapable of articulating or unfolding unless by means of oppositions. In Bradley summation, Derrida is of the view that:

'the 'metaphysics of presence' historically operates by erecting a series of binary oppositions between concepts, values or terms where, in each case, one concept is identified as the bearer of presence itself whereas the other is identified with the falling away, or loss of, that presence: the transcendental is privileged as more 'present' than the empirical, the ideal is championed over the material, the soul over the body, the masculine over the feminine and so on ad infinitum'(Bradley 2008: 6-7).

'Things, facts, and events ... in the form in which they actually occur at the given moment' said to be the real interest of Lesmian presses the case that the poet is constrained within the 'metaphysics of presence' of which the opposite, absence and negativity, fall outside his focus. But we see the thinking of nothing, void, absence in 'The Girl':

The wall fell down, a thousand echoes shook the hills and dales!

But on the far side: just a void. No living soul. No girl.

Nobody's eyes or mouth; no bed-of-roses destiny.

There'd been a voice, and just a voice, and nothing else you see.

Nothing - but grief and loss and tears and ignorance and night.

Such is the way of this evil world. Why isn't it put right?

In 'this evil world', the opposite of being is really nothingness; and an encounter with this otheras in 'The Girl' places an intolerable burden on consciousness with attendant 'grief and loss and tears and ignorance and night'. This order of the world demands to be put right. The insight, conceivably, is that -

'To attempt to think the opposite is stifling. And it is a question not only of thinking the opposite which is still in complicity with the classical alternatives, but of liberating thought and its language for the encounter occurring beyond these alternatives' (Writing and Difference 118).

In 'Pan Blyszczynski', the movement of thought briskly crosses from the space of being through that of 'nothing' to 'nothing's husk', 'beyond the world's far side'as the space of the action of the sequence. Its geographical reference points are provided, as well as its specific time markers:

When the nightmares are all busy with a quickened maring

Between the mist and the water, between mist and sky,

The hands of a green phantom disembody amid weeping

Above where pigweed, nettles and ferns lie (Second Stanza).

It is a time of nightmares - agents in their own right, rather than experiences suffered by some subject. Here, for example, 'the hands of a green phantom disembody amid weeping': the abstract noun phantom is coloured and has hands which nevertheless do not lose their identity when they disembody; there equally the weeping is not necessarily the action of a subject. The peculiar characteristics of this space are also noted, together with accustomed incidents. It is a place where,

Something like a golden island crawls in alleys far.

An island such as takes fright when brows raise ...

In a moment midnight creeps into the green with glow-worms' stars,

Disturbing the forest overgrowth's intricacies (Stanza 12).

The mobility of islands and midnight, the capacity of islands to take fright and midnight to disturb the intricacies of forest overgrowth mark them out as dissimilar to a real island or midnight, the sort that might be discussed in the space of being, things, and actual happenings. Transgressions upon commonsense, such as by these islands 
that are terrestrial and take 'fright when brows raise' are corrected by invoking one kind of device or another. Hence Stone speaks of 'anthropomorphization' (195). But just like Paul Coates's 'neologisms', 'anthropomorphization' marks the critic's resistance to the construction of an autonomous world 'following the poem's invitation' (Ricoeur 1984: 81).

In Lesmian's poetry a world similar to the real world is rare indeed, rather it is one that is dissimilar and other; and the incidents are unthinkable except within such unfamiliar environments. Such is the dream of the Twelve Brothers in 'The Girl':

Twelve brothers who gave credence to dreams tested the wall out from the dream's side.

For on its other side they heard a trapped girl as she cried.

It is a dream with spatial characteristics, the Brothers on 'the dream's side', the trapped girl's voice 'on its other side'. Similarly, the Ballad is a habitation, admittedly empty, in 'Uninhabited Ballad': it is in every sense 'the world's far side':

Beyond the reach of human eyes, where nobody could tread,

A meadow's emerald seclusion infinitely spread.

A stream lit out with ever-altered patches through the green,

And from behind the grass the cloves blossomed like cherry trees!

The jaws of the dew-bloated cricket darkened with foam.

Milk-drops topping slivers of stalks: the dandelions shone ...

The meadow breathed heat's live ferment, fermented and breathed,

And there was nobody around to hear a thing or see.

In this far off and alien world utterly out of range of observation and modification by human action, the productions of Nature are functioning in unlimited freedom, seclusion is richly green in colour and is the subject of its sentence and logical performer of the verb phrase spread, just like the stream abruptly lighting out'through the green'. The human entity, if found in these environments, is usually a stranger and ill at ease. In 'Uninhabited Ballad', it is a girl who attempts to come to be:

Out of the midst of hemlock something wondrous divined,

A girlish sort of mistiness in want of lips or eyes.

And one could sense her painful will to self-create, to incarnate,

Just once-wear golden-braided hair, display a breast of white.

And one could sense the anguish heaving, panting, in her womb-

Until her strength gave way for ever-left her unbecome!

But just there where she might have been some whispers of existence

Kept a blank space for that soul-for that body, a fragrance.

The 'girlish sort of mistiness' unable to self-create in the above lines reappears in 'Pan Blyszczynski', where she makes better progress, but doesn't quite cross the barrier of life. But the distance she has come is sufficiently disruptive for God to want to know:

'Who created her?' No one; she was lifeless when she came,

She has no death, she neither lived nor died ...

In vain I've combed her braids for being's traces, crumbs of dream,

In vain I yearn to stroke her golden curls.

And her unbeing moves me. Wondrous maid of the unbeen! ...

Be good to the unbeen ... I know You will ...

It is doubtful that she has substantiality of any sort. The Speaker of 'In vain I've combed her braids for being's traces', whose voice is firm and has substantiality, is unable to draw her into dialogue to establish an 'I - You' relationship which marks persons in discourse: She remains irremediably third person, thus absent; for as we read of the persons of discourse in Benveniste,

'The form that is called the third person really does contain an indication of a statement about someone or something but not related to a specific "person." The variable and properly "personal" element of these 
denominations [first and second persons] is here lacking.... the"third person" is not a "person"; it is really the verbal form whose function is to express the non-person'(197-198).

The dialogue is between the Speaker and God. These are the 'persons' in this poetic discourse. The Speaker makes appeal to God to 'Be good to the unbeen .... This girl I love' (Stanzas 19-20). Unlike in mythology, where Venus vouchsafes to give life to Pygmalion's statue he has fallen in love with, to Pan Blyszczynski's appeal, 'The Lord said not a word'. So the Girl, having moved beyond the 'painful will to self-create, to incarnate' and 'painful will to self-create, to incarnate' ('Uninhabited Ballad') to emergence 'from swaddling haze' to physical form in which her braids are combed just falls short of being. Only by God taking action will this happen. He does not; and so nothing fundamentally changes.

By contrast, in 'The Saw', the 'nightmare with its saw-like waist' quite wills herself from a saw that once 'set about a tree' into a human form, retaining her saw-like properties for the sake of the Boy she desires since her 'body wants to test itself against a new caress', unlike the habitual trees. With the willow tree waving its golden tresses above them,

The boy learned the strength of loving steel when it caresses.

Her love bites bit him into ones and twos:

'Ha! More than one soul will come out of you!'

Her kisses tore him into little bits-

'O little ones, I hope in death you have a good time of it!'

In 'Transformations', there is a clear sense that the world of stable identities is really the human world and therefore cannot share or know the other world beyond nothingness. Non-human objects enjoy the absolute freedom of becoming. Darkness pants with desire, cornflowers displace the eye of a deer, a poppy cockerels and crows, confusing 'real cockerels', which crow 'an answer back'. The human is too burdened with thought to be able to rise beyond itself:

And I-in what place was I stung, at what hour,

To make me creep by, through boundary strips, secretly?

Why is there suspicion in the eyes of the flowers?

Do they know of a night self of mine-unknown to me?

What is it I've done that my hands clutch my brow?

What thing was I last night, gone forever now?

The poems inscribe in their infrastructure what Fredric Jameson calls a 'strategy of containment', comprising a space in which the sequence plays out as its own natural environment. I have adopted as a general metaphor for it 'the world's far side'. But it can be a dream-space as in 'The Girl', seclusion as in 'Uninhabited Ballad', 'Refrain', and 'Bees', or forest as in 'The Saw', but it interconnects at various levels with the specific sequence unfolding or action taking place.

\section{The Discursive First Person}

In contrast to the Third Person who is absent at the scene of discourse, the First Person is present and marked by speech actionswhereby it may engage the Second Person in dialogue. It is in the strict sense a person; in its utterances there is reflected the state of his consciousness, quite unlike the third person whose utterances and consciousness are received by mediation. In 'The Saw', the one who identifies itself in the First Person is an inhuman figure, the 'nightmare with its saw-like waist', who targets the potentially speaking subject and psychological entity, the Ploughboy, for destruction. He has no chance against the Saw'svoluble discourse which is utterly lacking in the cues that would enable dialogue, nor against her love, delivered 'in harshest steel':

Her love bites bit him into ones and twos:

'Ha! More than one soul will come out of you!'

Her kisses tore him into little bits-

'O little ones, I hope in death you have a good time of it!'

She divided him up and flung him to opposite lands:

'Let God collect you again, offal of mankind!' 
A pure victim, he never opens his mouth: he is almost absent, except by virtue of the action of the Saw of which he is the sufferer. For her own part, all the speech actions as well as the physical actions are performed by the Saw. It is in her works that we have a full narration of what is foreshortened in 'Pan Blyszczynski' as a nightmare's 'quickened maring'.

More frequently, Lesmian's human subjects are found in the state of a profoundly troubled consciousness and regarding the natural objects around them with some sort of envy. In 'Evening', the human subject is a female figure 'seen from afar', her arms having,

To her chin. Under heaven's tent she has grown

gracefully gathered her knees

Ever more lonely in this clime and remoteness,

Having long preserved the same posture and dream,

Drinking in the numbed spell of just looking

At everything, and yet no single thing ...

Her depression is in marked contrast to the strength and energy of the natural objects, which are all free of the 'laws' of nature so that they scarce resemble themselves. In her situation of defeat, she recalls the 'person with knowledge', who 'began to know / and is silent now' in Rilke's 'Cast out on the Heart's Mountains'.In'Transformations', however, the human figure finds his voice and is able to put into words the sense of bewilderment and humiliation, the utter loss of self-confidence resulting from the natural objects reaching beyond their natural limits and creating new possibilities for themselves. He feels this boundless energy in things as 'a severe blow', as Freud would say (Ricoeur 1974: 152), to his sense of his own uniqueness in the universe, and addresses himself:

will what they experienced always remain a riddle?

And I-in what place was I stung, at what hour,

To make me creep by, through boundary strips, secretly?

Why is there suspicion in the eyes of the flowers?

Do they know of a night self of mine- unknown to me?

What is it I've done that my hands clutch my brow?

What thing was I last night, gone forever now?

He is no longer even sure of being protected by the natural 'invisibility' provided by individuality (Laing 1967), from being penetrated and the contents of his selfhood laid bare to these natural objects which, however, are protected from penetration by himself.

'The Drowned Man' enacts the fate of the subject defeatedand put to silence by the vitality of natural things, 'unmanning soul and breath', which he himself lacks. He ends up, 'a corpse that nobody needs'. But he is also a victim like the Ploughboy, oppressed not only by 'impatient melancholy', but also by a figure like the 'nightmare with a saw-like waist', whose weapon is here purely psychological:

The demon of Green, meanwhile, with the forests for his breath,

Enwrapped him when he halted by a tree along his path,

And lured him with a haste of ceaseless bloomings

And charmed with panting lips' secret unsmiling.

And tantalised him with the fragrant wrecks of the unbeen.

This drowning is not entirely accidental. The subject has been enwrapped, but he is also lured and charmed and tantalized with the situation 'the unbeen' had striven to emerge out of. The alternative to succumbing to psychological pressure from 'the demon of Green' is the path walked by Pan Blyszczynski.

Beginning with a garden, which he extroduces'with his flashing eyes', Pan Blyszczynski has broken into God's creation with his own creative activity, stamping'his rustling mark on the creations' of God's might, and disvoidingthe 'garden and this grass'.In acting within God's domain, he has reached beyond his limits, yielding to a kind of temptation, not from weakness, but from a Nietzscheanboldness. He takes responsibility and offers explanation for what he has done.

'The afterworld was full of dreams and gales and magic storms.

Lord, do not take away my fulfilled dreams!

'Twas I gave body to these trees. My motions they, my thoughts. , My wonders and my dews ... we are the same. 
These sadnesses and lineage less shadows - Lord, oh pardon

The misformed flowers I spun from the void.

The fault is mine. Lord, come into the garden,

The garden, which is mine, is mine ... O Lord.

Unlike the original transgressors in the Garden of Eden yielding to an impostor with a claim to a secret insight into God's real intention, Pan Blyszczynskihas yielded to a temptation to follow through the possibilities he has glimpsed in things, possibilities offered by his dreams. There is no call for repentance; rather he appeals to God for approval. Silently, he consents to be shown round, only to be confronted by the apparition of the 'unbeen' girl.

The plural first person in 'we are the same'is ambiguous between an affirmation of community and expansion of the voice to accommodate the discursive other, which in this case is God, and a narrative event referring to the third person - the creations - and confession of identity with these. These creations may then be pure objects of thought. They matter to the extent that God notices and pays attention. To Pan Blyszczynski, however, the appearance of the unbeen girl has swept everything else off the table. Meaning for him is now tied up with the being of the unbeen girl. He renders up a desperate love song, tries to detain and perhaps substantialize her in his discourse. But these are impotent words.

In 'Uninhabited Ballad' there is celebration of the unbeen girl's failure at the threshold of being:

Attracted by strange whispers, every herb and insect came apace,

Converging there in ferment, scenting an unheard-of trace,

The spider set his net in nothingness to catch her shadow's shade,

The bittern trumpeted the feast of fulfilment of the unmaid,

Dung-beetles played a passing, and crickets a welcome, song;

$\mathrm{Ah}$ ! Flowers wound themselves in wreaths to lie her grave along.

Collected on that sun-soaked spot, they all observed the festival-

Except for her, the might-have-been, who never came and never will.

The insects memorialize her, really 'her shadow's shade', but their moodis triumphant. Even though there is a grave in place, this is for them a festival. The voice of narration alone, which is a human voice, reflects a somber mood in sympathy with the defeated human will. This sympathy is shared by 'the void' and 'dusk'in 'Pan Blyszczynski' and the sombre mood sweeps through all levels of awareness both human and 'nature's. Even the Unbeen herself, since she has attained a measure of consciousness on her way towards becoming possibly a 'living soul', is also aware and rueful of her failure:

The void whistled through maples; in the hollow oak, dusk whined;

The moon illumined - death and a spider's web ...

Pan Blyszczynskiunderstood, began to wring his hands

And thought. 'She's slipping into nothingness.'

She blew to nothing, with all of the charms heaven wrought;

Along with her breast, and the pink juiciness at its tip.

In terrible self-pity, the body fell apart -

Half ignorant of that pity. And that - wasit ...

She did not die, but in the lake there perished her reflection.

Like Pygmalion, the mythical sculptor who fell in love with his own ivory creation, Pan Blyszczynski has fallen in love with the 'unbeen' girl who, in this case, is uncreated. For'she was lifeless when she came, / She has no death, she neither lived nor died ...' Venus would consent and give life to Pygmalion's creation, but God has turned a deaf ear to Pan Blyszczynski's earnest appeal. So she slips 'into nothingness', leaving the lover of 'her reflection' 'very, very pale'.

The God of 'Pan Blyszczynski' is the same kind of being that is encountered in mythology. He has much more power than the human entity, Pan Blyszczynski, but hardly omnipotent. He is certainly not omniscient or what the Scholastics, following Aristotle, would call Pure Act, but makes transition from potency to act. Pan Blyszczynski has been able to follow the possibilities of a dream through, but there are still borders and limits. The 'unbeen' girl is not able to cross the boundary of existence, nor could Pan Blyszczynski help her over it by reason of the urgency of his love - the same love which has driven the Twelve Brothers to bid 'farewell to the whole world' and take on the wall from their 'dream's side' to free the girl on the other side whose voice they 
have fallen in love with.God seems to be constrained within similar limits and boundaries and thus remains unmoved by the passionate appeal, 'Be good to the unbeen... I know You will ...' which he makes on his own behalf, and the entreaty, 'O God in heaven, when you bless and curse, be generous / To those who know they aren't and wish for being', which he makes on hers.

\section{Conclusion}

Heidegger has formulated the question of poetry in terms of who man is and where he is settling his existence. Our reading of Lesmian's poetry here suggests a similar preoccupation, which as in all literature involves constructions with an "unmarked "as if" (Ricoeur 2003: 298). But instead of 'a hypothetical or assumed relation to the external world' (Frye 74), where poetry appears 'as if' a rational discourse, a purely mythological moment bereft of threads of experience is in place. Instead of a presumptive imposition of sense based on models of experience outside the poems as in Paul Coates's reading, we have merely activated a dialogue in which threads from some of Lesmian's other poems have become expressive. Desire seems to be universally at work in these poems. Effortlessly, the 'natural' objects exceed themselves and attain their aims, whether it be changing their own nature or affecting the nature of another. Intelligent and potentially intelligent beings, on the other hand, perhaps because of that very intelligence, are hemmed in by borders and limits.

\section{Works Cited}

[1]. Barthes, Roland. Image - Music - Text. London: Fontana Books, 1977. Print.

[2]. Benveniste, Emile. Problems in General Linguistics. Miami: University of Miami Press, 1971. PDF.

[3]. Bradley, Arthur. Derrida's Of Grammatology. Edinburgh: Edinburgh University Press, 2008. PDF.

[4]. Brock, Werner. 'Introduction'. Being and Essence. Chicago: Henry Regnery, 1949. PDF

[5]. Coates, Paul. Words after Speech: A Comparative Study of Romanticism and Symbolism.London: Macmillan, 1986. Print.

[6]. Derrida, Jacques. Of Grammatology. Trans. GayatriChakravortySpivak. Baltimore: Johns Hopkins University Press, 1976. Print.

[7]. ---. Writing and Difference. Trans. Alan Bass. London: Routledge Classics, 2001. PDF.

[8]. Foucault, Michel. The Archaeology of Knowledge. London: Tavistock Publications, 1972. Print.

[9]. Frye, Northrop. Anatomy of Criticism. New York: Atheneum Publications, 1970. Print.

[10]. Heidegger, Martin. Existence and Being. Trans. Werner Brock. Chicago: Henry Regnery, 1949. PDF

[11]. Hervey, Sándor G.J. Axiomatic Semantics: A Theory of Linguistic Semantics. Edinburgh: Scottish Academic Press, 1979.

[12]. Holquist, Michael. Dialogism: Bakhtin and his World. 2nd ed. London: Routledge, 1990. PDF.

[13]. Jameson, Fredric. The Political Unconscious: Narrative as a Socially Symbolic Act. Ithaca, New York: Cornell University Press, 1981. Print.

[14]. Kristeva, Julia. Desire in Language: A Semiotic Approach to Literature and Art. Trans.T. Gora, et al., Oxford: Blackwell, 1980. Print.

[15]. Laing, R.D. The Politics of Experience andThe Bird of Paradise. London: Pelican, 1967. Print.

[16]. Ransom, John Crowe. 'Criticism Inc.'20 ${ }^{\text {th }}$ Century Literary Criticism. Ed. David Lodge. London: Longman, 1972. 228-39. Print.

[17]. Ricoeur, Paul. The Conflict of Interpretations: Essays in Hermeneutics. Evanston: Northwestern University Press, 1974. Print.

[18]. ---. The Rule of Metaphor: The Creation of Meaning in Language. Trans. Robert Czerny with Kathleen McLaughlin and John Costello. London: Routledge Classics, 2003. PDF.

[19]. ---. Time and Narrative. Vol. 1. Trans. Kathleen Mclaughlin and David Pellauer. Chicago: The University of Chicago Press, 1984. Print.

[20]. Stone, Rochelle Heller. Boleslaw Lesmian: The Poet and His Poetry. Berkley: University of California Press, 1976. Web.

[21]. Thompson, John B. Studies in the Theory of Ideology. Berkeley, Los Angeles: University of California Press, 1984. Print.

[22]. Todorov, Tzvetan. 'Reading as Construction'. The Reader in the Text. Ed. Susan R Suleiman and IngeCrosman. Princeton: Princeton, University Press, 1980. 67-82. Print.

[23]. Perry, Ralph Barton. The Approach to Philosophy. Project Gutenberg. 〈www.gutenberg.net>. 2008 